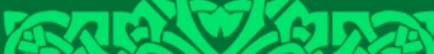
520030102 का 10 4 t

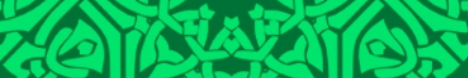
o 21205 रत्र 202 cos (2) 120

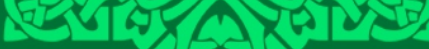
पis 4 कि

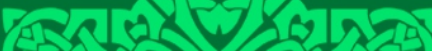
पित 1 (1) 0 (0)

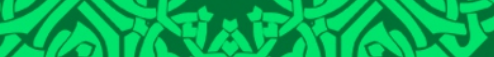
of 2505105 रन्तिए 0 cos 12 an

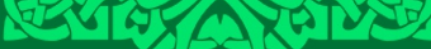
परत w कि Tat

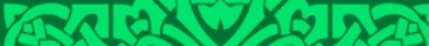
520100103 20 (1) 5 (5)
Sandra Dewi Dahlan, Mirotin Eka Wahyuningsih, Hasbi Assiddiqi, Edi Ardian, Rahmat Fajar The Role of Gossip as a Strategy to Reach Power in Tilik Short Movie

Hasaruddin, Sitti Mania, Ahmad Yani, Musyarif Tracking The Historical Development of Kedatuan Sawitto in South Sulawesi in The XVI-XVII Century

Abdul Muiz Amir, Sahiron Syamsuddin, Siswanto Masruri Dialectic Relationship Between The Qur'an and Hadith: The Interpretation of The Term "As-Sä'Ah" Using Critical Hermeneutic Analysis

Fachmi Alhadar, Safrudin Amin Covid-19 Poems as Cultural Response to Pandemic in Indonesia

Arini Indah Nihayaty, Bagong Suyanto, Sutinah A Study of Religious Symbols Attached to The Former Terrorist Convicts' Family as Seen in Social Interaction Wahyuddin, M. Abdul Hamid محاولات شوقي ضيف التجيديدية في تيسير النحو التعليمي

M. Napis Djuaeni, Hasyim Ashari نظام القافية ودوره في نشأَة المعاجم اللغوية العربية

Hasyim Haddade, Baso Pallawagau, Zaenal Abidin, Muhammad Zakir Husain التجديد في النحو: در اسة مذهب الخطيب الثربيني اللغوي في تفسيره السراج المنير

Nurhakki, Ahmad Sultra Rustan, Muhammad Taufiq Syam The Habituation of Tongkonan Communication as Adhesives for Religious Harmony in Toraja People

Nahdhiyah, Syahruni Junaid A Study of Al Qur'an towards Environmental Issues of Buginese ElongElong (Ecocritical Approach) UNIVERSITAS ISLAM NEGERI ALAUDDIN 


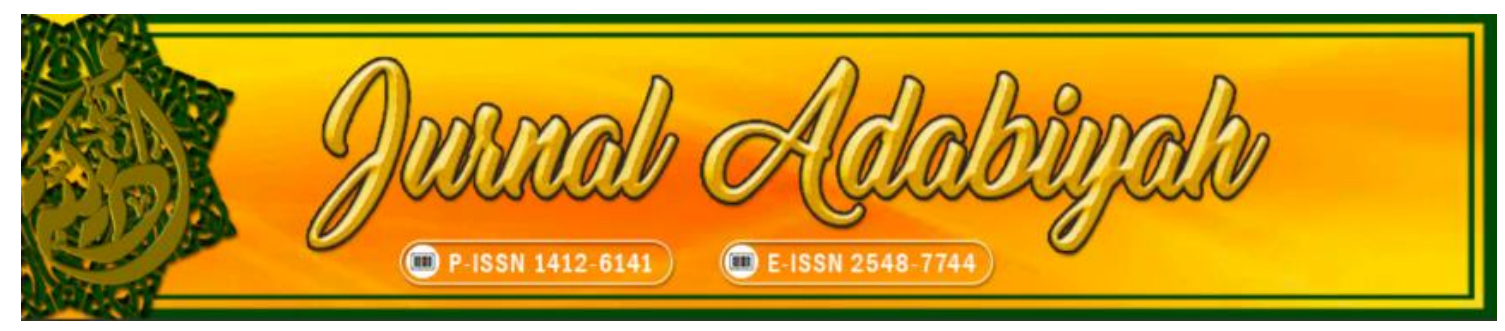

Theme: Humanities

VOLUME 21 NO. 1 JUNE 2021

\section{EDITOR-IN-CHIEF}

Nuri Emmiyati, Alauddin State Islamic University, Indonesia

\section{ASSOCIATE EDITOR}

Barsihannor, Alauddin State Islamic University, Indonesia

\section{INTERNATIONAL EDITORIAL BOARD}

Shamsi Ali, University of Northern California, United States

Miss Tiarne Jade Barratt, University of Sydney, Australia

Muhammad Widus Sempo, Universiti Sains Islam Malaysia, Malaysia

Salih Yousif Sharaf Mohamed, Al-Gazera University, Sudan

Aishah Waenaha Waemamah, Academy of Islamic and Arabic Studies Princess of Naradhiwas University

- Thailand, Thailand

\section{EXECUTIVE EDITOR}

Umar Thamrin, Alauddin State Islamic University, Indonesia

\section{MANAGING EDITOR}

Nasrum, Alauddin State Islamic University, Indonesia

\section{EDITORS}

Akbar Haseng, Institut Agama Islam Negeri Kendari, Indonesia Sardian Maharani Asnur, Alauddin State Islamic University, Indonesia Subehan Khalik Umar, Alauddin State Islamic University, Indonesia

Haniah, Alauddin State Islamic University, Indonesia

Andi Satrianingsih, Universitas Muhammadiyah Makassar, Indonesia

Awaluddin Syamsu, Universitas Muslim Indonesia

Muhammad Azwar, UIN Syarif Hidayatullah Jakarta, Indonesia

\section{ASSISTANT TO THE EDITORS}

Chusnul Chatimah Asmad, Alauddin State Islamic University, Indonesia

ENGLISH LANGUAGE ADVISOR

Rosmah Tami, Alauddin State Islamic University, Indonesia

Syahruni Junaid, Alauddin State Islamic University, Indonesia

\section{ARABIC LANGUAGE ADVISOR}

Muh. Saleh Syamsuri, Alauddin State Islamic University, Indonesia

Baso Pallawagau, Alauddin State Islamic University, Indonesia

\section{IT SUPPORT}

Taufiq Mathar, Alauddin State Islamic University, Indonesia

\section{COVER DESIGNER}

Nur Arifin 


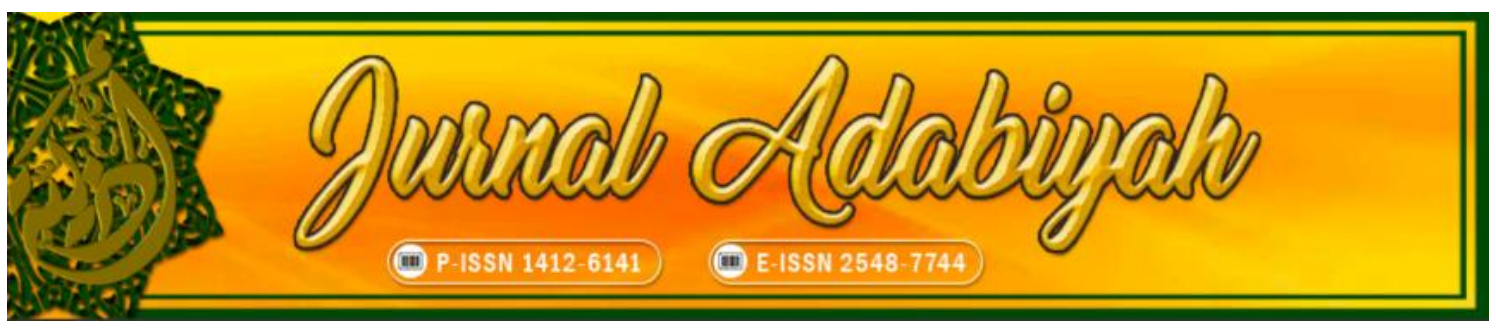

\section{Jurnal Adabiyah:}

This journal receives a national accreditation from Ministry of Research, Technology, and Higher Education Republic of Indonesia, Nomor 10/E/KPT/2019 on April 4, 2019 with the SINTA score: S2.

The Journal has been published by the Faculty of Adab and Humanity of Alauddin State Islamic University, Makassar, since 1997 and has been online since 2016 with the main themes on Humanities and Islamic Studies with the emphasis on interdisciplinary and intertextuality approach.

This journal are published twice a year, on June and December. The themes related to Islamic Studies are textual studies, scriptural traditions, Islamic law, and theology; and those related to Humanities are language, literature, history, and culture.

The journal of Humanities and Islamic Studies will provide the online collection of articles from 1997 up to now. The most updated information can be found on the website. 


\section{Table of Contents}

Besse Wahida, Khaerun Nisa Nuur, Ibnu Hajar Ansori

Tracing Entities of Arabic in The Qur'an

Sandra Dewi Dahlan, Mirotin Eka Wahyuningsih, Hasbi Assiddiqi,

Edi Ardian, Rahmat Fajar

The Role of Gossip as a Strategy to Reach Power in Tilik Short Movie

Hasaruddin, Sitti Mania, Ahmad Yani, Musyarif.

Tracking The Historical Development of Kedatuan Sawitto in South Sulawesi in The XVI-XVII Century

Abdul Muiz Amir, Sahiron Syamsuddin, Siswanto Masruri 57-81

Dialectic Relationship Between The Qur'an and Hadith: The Interpretation of The Term "As-Sā 'Ah" Using Critical Hermeneutic Analysis

Fachmi Alhadar, Safrudin Amin.

Covid-19 Poems as Cultural Response to Pandemic in Indonesia

Arini Indah Nihayaty, Bagong Suyanto, Sutinah

A Study of Religious Symbols Attached to The Former Terrorist Convicts' Family as Seen in Social Interaction

Wahyuddin, M. Abdul Hamid

محاولات شوقي ضيف التجبيليدية في تيسيل النحو الثعليهي

161-187

M. Napis Dj, Hasyim Ashari

نظام القافية ودوره في نشأة المعاجم اللغويا العربية

Hasyim Haddade, Baso Pallawagau, Zaenal Abidin,

Muhammad Zakir Husain

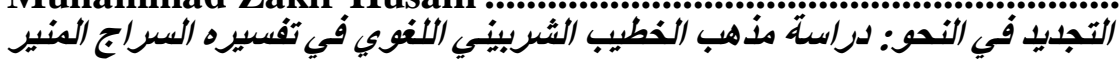

Nurhakki, Ahmad Sultra Rustan, Muhammad Taufiq Syam

The Habituation of Tongkonan Communication as Adhesives for Religious Harmony in Toraja People

Nahdhiyah, Syahruni Junaid

A Study of Al Qur'an towards Environmental Issues of Buginese ElongElong (Ecocritical Approach)

Jurnal Adabiyah Vol 21. Number 1/2021 


\title{
COVID-19 POEMS AS CULTURAL RESPONSE TO PANDEMIC IN INDONESIA
}

\author{
Fachmi Alhadar ${ }^{1}$, Safrudin Amin ${ }^{2}$ \\ Universitas Khairun Ternate North Maluku, Indonesia ${ }^{1,2}$ \\ Email: alfahmi.p55@gmail.com¹, Safrudinamin1@ gmail.com²
}

\begin{abstract}
Covid-19 has shocked entire world in almost all aspects of social and individual life. It appears that this pandemic has threaten individual and public health, infused political concerns between and within countries, and caused economic downturn. Studies on response to the pandemic have covered wide ranges of issues such as policies, psychological, economic, education etc. This article is interested in exploring how people response to this pandemic through the use of their cultural stocks, particularly the use of poetry. In so doing, this article samples two poems written government public figures. The poems are Corona Virus written by M. Jusuf Kalla, a former vice president of Indonesia, and Corona Virus Disease 2019 written by Sri Purnomo, the Regent of Sleman Yogyakarta, and analyses their contents. This study uses netnography method in collecting data and makes use of qualitative text analysis, particularly qualitative content analysis, in analyzing the available data. By using anthropological approach, this study interprets the interpretations of the pandemic via digging the content of their poems. This study found that interpretations of the pandemic expressed through poems focused on several main themes and that these themes were strongly shaped by their cultural values and beliefs. In other words, their poems are not a mere personal expression but also cultural responses to the covid-19 pandemic.
\end{abstract}

Keywords: Covid-19; Pandemic; Response; Poem; Culture.

$$
\text { الملخحص }
$$

لقد صدم Covid-19 العالم بأسره في كل جانب من جوانب الحياة الاجتماعياة

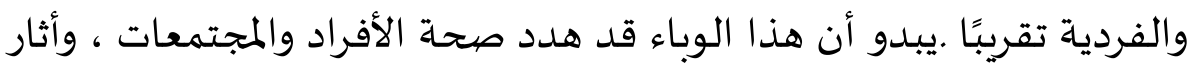

مخاوف سياسية بين البلدان وداخلها ، وتسبب في انكماش اقتصادي .غطت

الدراسات حول الاستجابة للوباء قضايا مختلفة مثل السياسة وعلم النفس

والاقتصاد والتعليم وغيرها .تهتم هذه المقالة باستكشاف كيفية استجابة

المجتمع لهذا الوباء من خلال استخدام مخزونهم الثقافي ، وخاصية استخدام

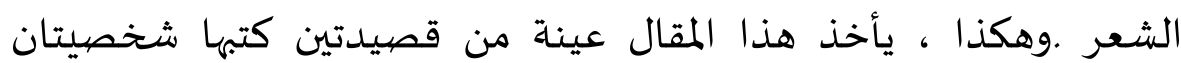




$$
\begin{aligned}
& \text { حكوميتان .القصائد هي فيروس كورونا كتبها م .تستخدم هذه الدراسـة طريقة } \\
& \text { في جمع البيانات وتستخدم التحليل النوعي للنص ، وخاصة } \\
& \text { تحليل المحتوى النوعي ، في تحليل البيانات المتاحة .باستخدام نهج أنثروبولوجي ، } \\
& \text { تفسر هذه الدراسة تفسير الوباء من خلال استخراج محتويات شعرهم . } \\
& \text { ووجدت الدراسـة أن تفسيرات الوباء المعبر عنها من خلال الشعر تركز على عدة } \\
& \text { مواضيع رئيسية وأن هذه الموضوعات تشكلت بقوة من خلال قيمهم الثقافية } \\
& \text { ومعتقداتهم .وبعبارة أخرى ، فإن قصائدهم ليست مجرد تعبير شخصي ، بل هي } \\
& \text { أيضًا استجاباة ثقافية لوباء.COVID-19 } \\
& \text { الكلمات المفتاحية: Covid-19؛ جائحة؛؛ إجاباة؛ شعر؛ حضـاره. }
\end{aligned}
$$

\begin{abstract}
Abstrak
Covid-19 telah mengejutkan seluruh dunia dihampir semua aspek kehidupan sosial dan individu. Tampaknya pandemi ini telah mengancam kesehatan individu dan masyarakat, menimbulkan kekhawatiran politik di antara dan di dalam negara, dan menyebabkan kemerosotan ekonomi. Kajian tentang respons terhadap pandemi telah mencakup berbagai isu seperti kebijakan, psikologis, ekonomi, pendidikan dan lain-lain. Artikel ini tertarik untuk mengeksplorasi bagaimana respons masyarakat terhadap pandemi ini melalui penggunaan stok budaya mereka, khususnya penggunaan puisi. Dengan demikian, artikel ini mengambil sampel dua puisi yang ditulis oleh dua tokoh publik pemerintah. Puisi tersebut adalah Corona Virus ditulis oleh M. Jusuf Kalla, seorang mantan wakil presiden Indonesia, dan Corona Virus Disease 2019 yang ditulis oleh Sri Purnomo, bupati Sleman Yogyakarta, dan menganalisis isinya. Penelitian ini menggunakan metode netnografi dalam mengumpulkan data dan menggunakan analisis teks kualitatif, khususnya analisis isi kualitatif, dalam menganalisis data yang tersedia. Dengan menggunakan pendekatan antropologi, penelitian ini memaknai interpretasi pandemi melalui penggalian isi puisi mereka. Studi ini menemukan bahwa interpretasi pandemi yang diungkapkan melalui puisi berfokus pada beberapa tema utama dan bahwa tema-tema ini sangat dibentuk oleh nilai-nilai budaya dan kepercayaan mereka. Dengan kata lain, puisi-puisi mereka bukan sekadar ekspresi pribadi tetapi juga respons budaya terhadap pandemi covid-19.
\end{abstract}

Kata Kunci: Covid-19; Pandemic; Respon; Puisi; Kebudayaan. 


\section{A. Introduction}

The world has been rocked by a new wave of viral pandemic since the end of 2019. Beginning from Wuhan, China, the virus has spread to various parts of the world across geographic boundaries, countries, and social identities. In Indonesia, the spread of the Covid-19 virus was revealed in March 2019. Although information about the dangers of this virus has been widely shared since the end of 2019, the central government has not taken serious steps in early stages of the pandemic ${ }^{1}$. There was even a tendency to take it lightly, as if the virus belongs to those far away (China) and will not reach Indonesia.

This outbreak has a multidimensional impact. The immediate impact of this outbreak is a massive health threat. In mid-March 2020, the number of infected cases in Indonesia was still below ten, growing to around 400 in mid-April, and to a total of 45,891 cases on June 21, 2020. The health impacts mentioned above also fuel psychological effects in the form of panic and even trauma. In fact, since the finding of the covid-19 case in mid-March, the public has begun to respond to this outbreak with panic. The government has repeatedly asked the public not to be panic but it seems that people have lost confidence in the government. Fear spreads to various regions at once and has far-reaching effects. Some rural areas have even taken the initiative to carry out their own lockdowns for protecting their villages. ${ }^{2}$ The psychological shock even permeate psychological trauma. Abdullah in his study of the impact of covid-19 in Indonesia noted that there are four domains of psychological trauma manifested in Indonesian society, namely social isolation, hysteria, individual violence, and collective violence. ${ }^{3}$

The Covid-19 outbreak also had an impact on political aspects, especially in disrupting the coordination between the central government and local governments in handling the outbreak. Not only are rural communities taking the village quarantine initiative, the central government's slow response to this pandemic has also been responded by several local governments by implementing regional quarantine measures. However, their move caused tensions with the central government since the central government rejected the regional government quarantine. ${ }^{4}$ In order to protect their people, some governors in several provinces have taken steps to implement social restrictions and territorial

1 Jefferson NG, "Can Indonesia's Fight against COVID-19 Overcome Troubled CentralRegional Coordination?," New Mandala, April 28, 2020, https:/www.newmandala.org/canindonesias-fight-against-covid-19-overcome-troubled-central-regional-coordination/.

2 Intan Kumalasari, "Viral, Ini 7 Potret Unik 'Lockdown' Di Berbagai Desa Di Indonesia," Merdeka, March 28, 2020, https:/www.merdeka.com/sumut/7-potret-unik-lockdown-di-berbagaidaerah-di-indonesia.html.

${ }^{3}$ Irwan Abdullah, "Psychological Trauma : Theory, Research, Practice , and Policy COVID19 : Threat and Fear in Indonesia," American Psychological Association, 2020. Coordination?"

4 NG, "Can Indonesia's Fight against COVID-19 Overcome Troubled Central-Regional 
quarantine. The governor of DKI province, Anies Baswedan, was the first to take these steps. President Jokowi rejected his policy, ${ }^{5}$ and the central government indeed canceled Annies Baswedan's three policies, namely restricting public transportation, stopping AKAP bus services, and regional quarantine. ${ }^{6}$ In Papua, the Regent of Sorong and the Governor of Papua province, for example, took a regional quarantine measures by prohibiting all activities from leaving or entering their territories, but the central government rejected the steps. ${ }^{7}$

On the economic aspect, the impact of the Covid-19 outbreak is estimated to be quite huge. President Jokowi ${ }^{8}$ estimates that Indonesia's economy will face very heavy challenge and economic growth could even reach minus 3\%. This impact on the economy will hit four main sectors, namely households, MSMEs, corporations and the financial sector. ${ }^{9}$ Susilawati, Falefi, and Purwoko's study reveals that the sector most affected is the household economy. ${ }^{10}$ This impact on the economy leads to increased unemployment and poverty. A survey conducted by the World Labor Organization (ILO) of 571 companies in April revealed that $90 \%$ of companies are experiencing financial problems and about $63 \%$ of the companies surveyed have reduced the number of workers. It also found that many other companies were planning to do the same. ${ }^{11}$ The Chamber of Commerce and Industry (KADIN) estimated that the number of layoffs could reach 15 million workers throughout Indonesia. $^{12}$

The pictures of the impacts of covid-19 on public health, psychological, political, and socio-economic aspects, both from media reports and research findings,

${ }^{5}$ Marchio Irfan Gorbiano and Budi Sutrisno, "Jokowi Refuses to Impose Lockdown on Jakarta," 2020.

${ }^{6}$ Supriatin, “3 Kebijakan Anies Baswedan Dibatalkan Pemerintah Pusat,” Merdeka, April 1, 2020, https://www.merdeka.com/jakarta/3-kebijakan-anies-baswedan-dibatalkan-pemerintahpusat.html.

7 Dian Erika Nugraheny, "Mendagri Tak Setuju Pemprov Papua Tutup Wilayah Akibat Covid-19," Kompas, March 2020, https:/nasional.kompas.com/read/2020/03/25/07591621/mendagri-tak-setuju-pemprov-papua-tutupwilayah-akibat-covid-19?page=all.

8 Andhika Prasetyo, "Presiden: Ekonomi Indonesia Akan Sangat Berat," Media Indonesia, June 19, 2020, https://mediaindonesia.com/ekonomi/321836/presiden-ekonomi-indonesia-akansangat-berat.

9 Antara, Adinda Pryanka, and Sapto Andika Candra, "Empat Sektor Ekonomi Yang Paling Tertekan Pandemi Covid-19," 2020.

10 Susilawati Susilawati, Reinpal Falefi, and Agus Purwoko, "Impact of COVID-19's Pandemic on the Economy of Indonesia," Budapest International Research and Critics Institute (BIRCI-Journal): Humanities and Social Sciences, 2020, https://doi.org/10.33258/birci.v3i2.954.

11 Rezha Hadyan, "Survei ILO: Dua Dari Tiga Perusahaan Di Indonesia Berhenti Beroperasi," Ekonomi Bisnis, $\quad$ May $\quad 18, \quad 2020$ https://ekonomi.bisnis.com/read/20200518/12/1242174/survei-ilo-dua-dari-tiga-perusahaan-diindonesia-berhenti-beroperasi.

12 Cnnindonesia.com, "Bukan 2 Juta, Kadin Sebut Korban PHK Akibat Corona 15 Juta," 2020. 
have enriched our insights on the multidimensionality of the pandemic. However, as has been shown in earlier paragraphs that there have been some studies that have covered impacts on health, psychology, politics, and socio-economic, but rarely we find studies on the impact on culture. In other words, there is very little attention to the impact of this pandemic on culture. This study, therefore, seeks to fill the gap that exists in the present studies. Certainly there are many impacts of this pandemic on cultural life. This study's attention, however, is not on negative impacts but rather on positive impacts namely cultural creativity in responding to the Covid-19 pandemic. This study focuses especially in the realm of cultural production in response to the Covid-19 pandemic in Indonesia.

Theoretically, people will always carry out cultural production because cultural development is part of everyday social life. However, in general, cultural production that takes place in normal situations encounters heavy pressure when facing massive disasters such as pandemic. Even normal cultural mechanisms can collapse and become dysfunctional when faced with a disaster or disease outbreaks. In some cases normal cultural mechanisms collapsed and became abandoned when facing abnormal situations such as natural disasters and disease outbreaks. In several African countries, natural disasters in the form of drought, for example, have destroyed the cultural apparatus of society, which had functioned well in normal situations. ${ }^{13}$

In connection with the Covid-19 outbreak, although the Covid-19 pandemic has resulted in the simplification, adjustment, postponement, and even the cancellation of many cultural activities, this pandemic has not dampened human cultural creativity to produce (and reproduce) culture in response to the the pandemic. The concept of cultural production itself, although it has been widely used, is an elusive concept and is not easily agreed upon by experts in the socio-humanities field In fact, it can be said that it tends to be difficult to find an explicit definition of this concept and its scope. Some experts see cultural production as part of economic activity in the cultural realm. This perspective, then, places cultural production as part of the cultural industry or a new economic form. ${ }^{14}$

This way of placing culture in a position no longer autonomous and under industrial (economic) control has actually been one of the objections of scholars for a long time. Max Horkheimer and Theodor Adorno, for example, in Dialectic of the

${ }^{13}$ J. W. M. van Dijk, "Livestock Transfers and Social Security in Fulbe Society in the Hayre, Central Mali," in Coping with Insecurity: An Underall Perspective on Social Security in the Third World, 1994, 97-112; M.E. de Bruijn, "The Sahelian Crisis and the Poor: The Role of Islam in Social Security among Fulbe Pastoralists, Central Mali," Focaal: Tijdschrift Voor AntropologieFocaal 22/23, no. 47 (1994).

${ }^{14}$ Dominic Power and Allen J.Scott, Cultural Industries and the Production of Culture, ed. Dominic Power Allen J.Scott, 1st ed. (New York: Routledge, 2004). 
Enlightenment describe this phenomenon as part of cultural degradation where culture loses its authentic meaning and becomes part of the reproduction of capitalism. ${ }^{15}$

Among anthropologists, the concept of cultural production, whether used explicitly or implicitly, shows quite wide variations because it depends on the phenomena being studied and the theoretical orientation on which they are based. Some circles see cultural production as part of the political-cultural mechanism in the nationalism project of a nation-state as well as fulfilling commercial interests. Anthropologist such as Abu-Lughod, for example, wrote that cultural producers "are working within structures of power and organizations that are tied to and doing the work of national or commercial interests". ${ }^{16}$ In line with Abu-Lughod, anthropologists who concentrate on studying nationalism as a cultural project consider the production and reproduction of culture as a political-cultural project of nationalism. ${ }^{17}$

In local or in the sub-national levels, cultural production and reproduction are often part of the contestation over natural and social resources from different groups. 18 explores the cultural movement of Ajeg Bali, a movement that aims to strengthen and protect Balinese culture but contains a strong tendency to produce and strengthen Balinese ethnic identity while excluding immigrant groups. Cultural production in the forms of identity construction and customary politicization were also found by Tania Li in Central Sulawesi, ${ }^{19}$ Maribeth Erb in West Flores, ${ }^{20}$ and Eindhoven in the Mentawai Islands. ${ }^{21}$

Although many studies have shown that cultural production is often part of identity construction, it does not necessarily mean that cultural production is always dealing with identity construction. The studies focusing on identity-building as discussed earlier are unable to reveal any phenomenon of cultural production that take place outside identity and political contest. This study focuses on this non-political cultural production, particularly the creation of literary works in the forms of poems as response to covid-19 pandemic. In general, cultural production is often a response to situations within or outside the boundaries of the culture itself, both to social and Lane, 1972)

15 Max Horkheimer and Theodor Adorno, Dialectic of the Enlightenment (London: Allen

16 Lila Abu-Lughod, "The Interpretation of Culture(s) after Television," in The Fate of "Culture": Geertz and Beyond (Berkeley: University of Califronia Press, 1999).

${ }^{17}$ Ernest Gellner, $N$ Ations and $N$ Ationalism, 1st ed. (New York: Cornell University Press, 1983); R. Foster, "Making National Cultures In The Global Ecumene," Annual Review of Anthropology 20, no. 1 (1991): 235-60, https://doi.org/10.1146/annurev.anthro.20.1.235.

18 H. S Nordholt, "Bali: Sebuah Benteng Terbuka," in Politik Lokal Di Indonesia, ed. H.S. Nordholt and G. van Klinken (Jakarta: Yayasan Obor, 2007).

${ }^{19}$ Tania M. Li, “Adat Di Sulawesi Tengah: Penerapan Kontemporer,” in Adat Dalam Politik Indonesia, ed. Jamie S. Davidson, David Henley, and Moniaga Sandra (Jakarta: KITLV, 2010).

${ }^{20}$ Erb Maribeth, "Kebangkitan Adat Di Flores Barat: Budaya, Agama, Dan Tanah," in Adat Dalam Politik Indonesia, ed. David Henley Jamie S. Davidson and Sandra Moniaga (KITLV, 2010).

${ }^{21}$ Myrna Eindhoven, "Penjajah Baru? Identitas, Representasi, Dan Pemerintahan Baru, Di Kepulauan Mentawai Pasca-Orde," in Politik Lokal Di Indonesia, ed. H.S. Nordholt and G. van Klinken (Jakarta: Yayasan Obor, 2007), 87-115. 
natural situations, by using the internal resources in the culture. This study considers cultural production as an indication of the creative process that cultural producers have in both making meaning of and facing against Covid-19 disease outbreak. In this context, culture is no longer understood as Geertz's proposal which treats culture as a system of solid shared meaning, passed down from generation to generation. ${ }^{22}$ Rather, culture is seen as an ongoing process that involves culture infuses human activity, and human creativity modifies and (re)produces culture. ${ }^{23}$

The cultural production in the forms of poems analysed in this study not only reflecting individual creativity but also reflecting the socio-cultural context in which the poems were born, and the agentive capacity of the writers who innovate their culture in creative ways. Here, a poem is not seen as something born from divine inspiration or an asocial empty space, rather it is but born in a certain socio-cultural context. Michael R. Hill calls "poetry is a sociological reality". ${ }^{24}$ Thus, this study argues that the poems written by the two public figures are responses to and reflections of realities, both sociocultural and natural realities. In brief, they are responses to the reality of covid-19 pandemic and reflection of their culture's ways of making meaning of the pandemic.

Cultural production, as discussed earlier, is a concept with a broad meaning. This study, however, focuses only on the producing of poems in responding covid-19 pandemic. More specifically, this study focuses on poems related to Covid-19 written by non-literary circles, namely public figures who are retired government official and active government official in Indonesia. The poems are Corona Virus written by M. Jusuf Kalla, a former vice president of Indonesia, and Corona Virus Disease 2019 written by Sri Purnomo, the Regent of Sleman Yogyakarta. There are two reasons for choosing these two figures and their poems. First, as far as can be traced, there are not many public figures from the government, both active and retired, write poem as an expression in response to the COVID-19 pandemic. Most government figures have responded to this pandemic in a very formalistic way based on formal rules or policies. These two figures were able to transcend the tradition of rigid expression and communication through the expression of the poetry they wrote and read them publicly. Second, these two government figures not only present the cultural views of the Indonesian people in the form of beliefs, values, and world views in dealing with the pandemic, but their poems also contain the message of a public leader to the people. The chosen dictions reflect a sense of being a leader who has concern for the fate of their nation and people. In this sense, their poems add value to the character of leaders who have concerns and responsibilities towards their nation and people.

\footnotetext{
${ }^{22}$ Clifford Geertz, The Interpretation of Cultures (New York: Basic Books, 1973).

23 Pierre Bourdieu, Outline of a Theory of Practice, Outline of a Theory of Practice (Cambridge: Cambridge University Press, 1977), https://doi.org/10.1017/cbo9780511812507.

${ }^{24}$ Michael R. Hill, Sociology and Poetry: An Introduction (Sociological Origins 4: Spring, 2006), https://digitalcommons.unl.edu/sociologyfacpub/356.
} 
Regarding to the theoretical paradigm of cultural production, the main question in this study is how cultural production in the form of poems become part of cultural response to the pandemic. This study, therefore, explores cultural values contained in the poems about Covid-19 written by the two non-poets public figures.

\section{B. Materials and Methods}

The data of cultural production analysed in this study are two poems written by two public figures. The poems were written in response to the Covid-19 pandemic that hit Indonesia since March 2020. Since this study relies on data sources available on the internet, the data collection uses netnography, an ethnography which makes the internet a research field, ${ }^{25}$ or more precisely passive netnography. ${ }^{26} \mathrm{We}$ collected data from various websites on the internet and selected two poems written by public figures as the units of analysis. They were chosen to explore not only the authors' views on the Covid-19 pandemic but also the values, norms, beliefs, and world-views behind their poems.

Since this study treats poems as text and the text is part of the document, this study uses document analysis method to examine and interpret data in order to draw meaning, gain understanding, and develop empirical knowledge. ${ }^{27}$ Unlike the tradition in literary analysis of poetry, the analysis of this study uses the tradition in social science, which emphasizes poems as documents containing socio-cultural information. The kind of document analayis utilized here is qualitative content analysis $^{28}$ with the purpose is to find the main themes in the poems. After the data collection, the analysis process begins with the classification of the poetry text into meaning units, squeezes them into condensed meanings, and then interpretations are carried out to find sub-themes and main themes of the poems. This gradual process reveals the perceptions, world-views, values, norms, hopes, beliefs, emotions, which also reflect the views, values, beliefs and expectations of the wider community.

\section{Results and Discussion}

This section will present two poems written by two public figures. The first writer is the former vice president of Indonesia and the other is an active official, the regent of Sleman. Both of them are not poets, but they express their views, feelings, ideas, and hopes about the Covid-19 outbreak through their poems, which are

25 R Kozinets, Netnography: Doing Ethnography Research Online (London: SAGE Publications, Inc, 2010).

26 Leesa Costello, Marie-Louise McDermott, and Ruth Wallace, "Netnography," International Journal of Qualitative Methods 16, no. 1 (December 2017): 160940691770064, https://doi.org/10.1177/1609406917700647.

${ }^{27}$ Corbin J., \& Strauss, A., Basic of Qualitative Research: Techniques and Procedures for Developing Grounded Theory (3rd Edition), 3rd ed. (Thousand Oaks: SAGE Publications, Inc, 2008).

${ }^{28}$ Michael Quinn Patton, Qualitative Research \& Evaluation Methods, 4th ed. (California: SAGE Publications, Inc, 2015). 
certainly worth studying academically. It is worth studying because in general poems written by figures outside the literary circles has received less attention in the academic world, therefore, it has been under-studied. In the view of anthropology, however, the poems written by non-literary circles are as important as those written by literary circles. It is because these poems reflect culture, a stock of knowledge and habitus that guide how to interpret a reality and how to respond to that reality as well as the values, beliefs, feelings, ideas, and worldviews that are involved in the whole process. With that in mind, the two poems written by retirees and active officials are also worthy of academic research. In addition, the poems written by the two government officials (retired and active) also contain certain contents about the views of officials (retired or active) on the fate of the nation and their people who are under the threat of the COVID-19 pandemic.

\section{Corona Virus by M. Jusuf Kalla}

In 2020, when the Covid-19 pandemic hit the world including Indonesia, Muhammad Jusuf Kalla also responded it. One of the responses was in the form a poem entitled Corona Virus, which he uploaded to his Instagram account on March 28, 2020. ${ }^{29} \mathrm{We}$ present the poem in bahasa Indonesian followed by an English translation.

\section{Corona Virus}

Semua bermula dari Wuhan

Menyebar kemana-mana tanpa pemberitahuan

Melampaui batas negara dan jabatan

Memapar segala bangsa tanpa ampun

Di Korea menyebar dari tempat peribadatan

Melanda Qom, tempat suci Syiah di Iran

Di Italia merebak di kota mode Milan

Di negeri ini diawali di tempat hiburan

Hari-hari ini penuh dengan kekhawatiran

Di mana doa terbaik sudah dipanjatkan

Bekerja, belajar, dan ibadah sudah dirumahkan

Menunggu nasib baik penuh harapan

Ya Tuhan, berilah kepada para ahli, kemampuan

Untuk menemukan yang dicari, obat dan vaksin

Sebagaimana janji-Mu, bahwa semua penyakit ada obatnya

Agar kami dapat beribadah lagi di masjid dengan gembira

Kepada bangsa, bersatu dengan penuh semangat

Semua dapat membantu sesuai kemampuan

${ }^{29}$ Republika.co.id, “Ini Puisi JK Soal Pandemi Covid-19,” 2020. 
Bagi yang ahli membantu yang sakit

Bagi yang mampu membantu yang rentan

Kepada para dokter dan perawat, terima kasih atas ketulusan

Dan atas upaya yang penuh risiko dan pengorbanan

Kepada para relawan, terima kasih atas pengabdian

Akhirnya kepada Allah jualah kami memohon

(Jakarta, 28 Maret 2020.)

English Translation of the Poem is as follows:

\section{Corona Virus}

\section{Jusuf Kalla}

From Wuhan it all began

Spread out everywhere without a word

Went beyond state boarders

And neglected ranks and positions

Mercilessly infecting whoever found

In Korea it emerged from worship places

It surged in Qom, the Holy Shiite place in Iran

In Italy it spilled over from the fashion city of Milan

In this country it started from a café

Our lives are filled with horror these days

And the best prayer is already offered

From home we work, we learn, and we worship

While waiting for the hopeful fortune

Oh God, please give the experts

A way to discover what is wanted, medication and vaccine

As You have promised us in the Quran;

That each disease has its medicine

So that we can worship again in the mosque with joy

To the nation, let's unite vigorously

All of us can contribute to our capacity;

The experts help the sick,

The haves should help the poor.

Those with strength are to help the weak.

To all doctors and caregivers, we thank you for the sincerity

All the risks you take and your sacrifices, we do appreciate,

To all the volunteers, our countless gratitude is addressed for

All the jobs you have devoted 
And to Allah and only He, hope and save we beg.

(Jakarta, 28 March 2020)

Tabel 1.

Content analysis of the Poem Corona Virus

\begin{tabular}{|c|c|c|c|c|}
\hline Meaning units & $\begin{array}{c}\text { Condensed } \\
\text { Meaning Units }\end{array}$ & $\begin{array}{c}\text { Interpretations } \\
\text { of condensed } \\
\text { meaning }\end{array}$ & Sub-theme & Theme \\
\hline $\begin{array}{l}\text { From Wuhan it } \\
\text { all began Spread } \\
\text { out everywhere } \\
\text { without a word } \\
\text { Went beyond } \\
\text { state boarders } \\
\text { And neglected } \\
\text { ranks and } \\
\text { positions. } \\
\text { Mercilessly } \\
\text { infecting } \\
\text { whoever found }\end{array}$ & $\begin{array}{l}\text { The corona } \\
\text { virus started in } \\
\text { Wuhan then } \\
\text { spread across } \\
\text { national borders } \\
\text { and social status }\end{array}$ & $\begin{array}{l}\text { The virus } \\
\text { spreads } \\
\text { regardless of } \\
\text { the country's } \\
\text { spatial } \\
\text { boundaries and } \\
\text { social status }\end{array}$ & $\begin{array}{l}\text { Corona } \\
\text { viruses } \\
\text { crosses } \\
\text { spatial and } \\
\text { social } \\
\text { boundaries }\end{array}$ & \multirow[t]{2}{*}{$\begin{array}{l}\text { The virus } \\
\text { spreads } \\
\text { across } \\
\text { spatial, } \\
\text { social, } \\
\text { sacred and } \\
\text { profane } \\
\text { boundaries. }\end{array}$} \\
\hline $\begin{array}{l}\text { In Korea it } \\
\text { emerged from } \\
\text { worship places, } \\
\text { It surged in } \\
\text { Qom, the Holy } \\
\text { Shiite place in } \\
\text { Iran } \\
\text { In Italy it spilled } \\
\text { over from the } \\
\text { city of mode, } \\
\text { Milan } \\
\text { In this country it } \\
\text { started from a } \\
\text { café }\end{array}$ & $\begin{array}{l}\text { The virus } \\
\text { spreads in } \\
\text { places of } \\
\text { worship as well } \\
\text { as in modern } \\
\text { lifestyle centers. }\end{array}$ & $\begin{array}{l}\text { The virus } \\
\text { spreads } \\
\text { anywhere, } \\
\text { including in the } \\
\text { sacred and } \\
\text { profane } \\
\text { domains. }\end{array}$ & $\begin{array}{l}\text { Corona } \\
\text { crosses the } \\
\text { boundaries } \\
\text { of the } \\
\text { sacred and } \\
\text { profane } \\
\text { realms }\end{array}$ & \\
\hline $\begin{array}{l}\text { Our lives are } \\
\text { filled with } \\
\text { horror these }\end{array}$ & $\begin{array}{l}\text { Anxiety spread, } \\
\text { people pray and } \\
\text { try to move } \\
\text { places of study, }\end{array}$ & $\begin{array}{l}\text { People worry, } \\
\text { pray and } \\
\text { change habits, } \\
\text { and hope for the }\end{array}$ & $\begin{array}{l}\text { In the face } \\
\text { of this } \\
\text { epidemic } \\
\text { human has }\end{array}$ & $\begin{array}{l}\text { Combining } \\
\text { spirituality } \\
\text { and real } \\
\text { action to }\end{array}$ \\
\hline
\end{tabular}




\begin{tabular}{|c|c|c|c|c|}
\hline $\begin{array}{l}\text { days } \\
\text { And the best } \\
\text { prayer is already } \\
\text { offered } \\
\text { From home we } \\
\text { work, we learn, } \\
\text { and we worship } \\
\text { While waiting } \\
\text { for hopeful } \\
\text { fortune. }\end{array}$ & $\begin{array}{l}\text { work, and } \\
\text { worship to their } \\
\text { homes. }\end{array}$ & best results. & $\begin{array}{l}\text { prayed and } \\
\text { taken } \\
\text { actions. }\end{array}$ & $\begin{array}{l}\text { face the } \\
\text { outbreak. }\end{array}$ \\
\hline $\begin{array}{l}\text { Oh God, please } \\
\text { give the experts } \\
\text { a way to } \\
\text { discover what is } \\
\text { wanted, } \\
\text { medication and } \\
\text { vaccine, As You } \\
\text { have promised } \\
\text { us in the Quran; } \\
\text { That each } \\
\text { disease has its } \\
\text { medicine. } \\
\text { So that we can } \\
\text { worship again in } \\
\text { the in mosque } \\
\text { with joy }\end{array}$ & $\begin{array}{l}\text { Pray that } \\
\text { experts will find } \\
\text { a cure and } \\
\text { vaccine for the } \\
\text { corona virus so } \\
\text { that Muslims } \\
\text { can worship at } \\
\text { the mosque } \\
\text { again. }\end{array}$ & $\begin{array}{l}\text { The discovery } \\
\text { of drugs and } \\
\text { vaccines is a } \\
\text { way to return to } \\
\text { worship in } \\
\text { mosques. }\end{array}$ & $\begin{array}{l}\text { Longing to } \\
\text { worship at } \\
\text { the mosque }\end{array}$ & $\begin{array}{l}\text { Longing to } \\
\text { worship at } \\
\text { the mosque }\end{array}$ \\
\hline $\begin{array}{l}\text { To the nation, } \\
\text { let's unite } \\
\text { vigorously. All } \\
\text { of us can } \\
\text { contribute to our } \\
\text { capacity; } \\
\text { The experts help } \\
\text { the sick, } \\
\text { The haves } \\
\text { should help the } \\
\text { poor. Those }\end{array}$ & $\begin{array}{l}\text { Urging the } \\
\text { Indonesian } \\
\text { people to unite } \\
\text { and provide } \\
\text { assistance to the } \\
\text { sick and } \\
\text { vulnerable in } \\
\text { dealing with the } \\
\text { corona } \\
\text { outbreak. }\end{array}$ & $\begin{array}{l}\text { A leader urges } \\
\text { to unite and } \\
\text { help each other } \\
\text { among } \\
\text { members of a } \\
\text { nation in } \\
\text { dealing with the } \\
\text { corona virus. }\end{array}$ & $\begin{array}{l}\text { The } \\
\text { importance } \\
\text { of unity and } \\
\text { mutual help } \\
\text { in the frame } \\
\text { of } \\
\text { nationhood }\end{array}$ & $\begin{array}{l}\text { Unity and } \\
\text { mutual } \\
\text { help as } \\
\text { members } \\
\text { of one } \\
\text { nation. }\end{array}$ \\
\hline
\end{tabular}




\begin{tabular}{|c|c|c|c|c|}
\hline $\begin{array}{l}\text { with strength are } \\
\text { to help the } \\
\text { weak. }\end{array}$ & & & & \\
\hline $\begin{array}{l}\text { To all doctors } \\
\text { and caregivers, } \\
\text { we thank you } \\
\text { for the sincerity. } \\
\text { All the risks you } \\
\text { take and your } \\
\text { sacrifices, we do } \\
\text { appreciate, To } \\
\text { all the } \\
\text { volunteers, our } \\
\text { countless } \\
\text { gratitude is } \\
\text { addressed for } \\
\text { All the jobs you } \\
\text { have devoted }\end{array}$ & $\begin{array}{l}\text { Thank you to } \\
\text { the paramedics } \\
\text { and volunteers } \\
\text { for the sacrifice } \\
\text { and service that } \\
\text { was full of } \\
\text { risks. }\end{array}$ & $\begin{array}{l}\text { Appreciation } \\
\text { for the } \\
\text { contribution of } \\
\text { paramedics and } \\
\text { volunteers }\end{array}$ & $\begin{array}{l}\text { Recognition } \\
\text { of the role } \\
\text { of medics } \\
\text { and } \\
\text { volunteers. }\end{array}$ & $\begin{array}{l}\text { Upholding } \\
\text { the value } \\
\text { of sacrifice } \\
\text { and } \\
\text { devotion. }\end{array}$ \\
\hline $\begin{array}{l}\text { And to Allah } \\
\text { and only He, } \\
\text { hope and save } \\
\text { we beg. }\end{array}$ & $\begin{array}{l}\text { Finally, we ask } \\
\text { Allah for help }\end{array}$ & $\begin{array}{l}\text { Acknowledge } \\
\text { God's power } \\
\text { and human } \\
\text { weakness }\end{array}$ & $\begin{array}{l}\text { Dependence } \\
\text { on Allah }\end{array}$ & $\begin{array}{l}\text { Allah is the } \\
\text { supreme } \\
\text { protector }\end{array}$ \\
\hline
\end{tabular}

Jusuf Kalla is a successful businessman as well as a skilled state official. He has held the position of vice president twice and has great concern with the progress of the Indonesian people and the nation. The poem, written at the end of March 2020, shows his concern with the huge threat the Covid-19 outbreak poses to Indonesian people and the nation. One strong theme in the poem is that of the virus's ability to transcend spatial and social boundaries. Viruses cross borders between countries so easily, and can even enter not only profane spaces with worldly hustle and bustle but can also penetrate into sacred spaces with full of the spirit of sacredness. This unit of meaning seems to give cautionary advice that this virus does not consider social status, national boundaries, and profane and sacred boundaries.

In another meaning unit, the author expresses the socio-cultural reality that, in facing the threat of the corona virus, humans are not only to pray with the best prayers they can, but also to make efforts to prevent the spread of the virus. One of the efforts is in the form of changing the culture of work, study, and worship from office, school, and mosque to work from home, learn from home, and worship from home. 
In another part, Jusuf Kalla also expressed his longing for the mosque as a place of worship for Muslims. This unit of meaning represents the social reality of the appeal of scholars and the government that, during the Covid-19 pandemic, it is better for all people to perform their worship in their homes with family. In some areas in Indonesia that implement large-scale social restrictions (PSBB), it is prohibited to perform worship in mosques. This forces many people who usually perform their prayers five times a day at mosques to move to their respective homes. In the mosque, they usually worship and also carry out various recitation activities and develop close social interactions among the congregation. All the atmosphere is completely lost when they have to worship at home. Longing for the atmosphere of the mosque is indeed much expressed in various conversations on social media, and even in poems, including this poem written by Jusuf Kalla.

Jusuf Kalla also did not forget to emphasize the theme of nationhood by urging the importance of unity and urged all parties to take part in the efforts to fight against the threat of the Covid-19 pandemic based on their respective abilities. This is a typical expression of a nation's leader (even though he is retired). This unit of meaning and theme reveals ideal leadership values as a leader who has concern for the fate of the nation and its people in a very threatening pandemic. This meaning is reinforced by its high appreciation for the doctors, nurses, and volunteers who have fought on the front lines in the face of the spread of the Covid-19 virus. In many mainstream media and social media medics are often portrayed as heroes in the fight against Covid-19. Some of the key words in this unit of meaning are sacrifice, dedication, full of risk, and sincerity are indeed the key characteristics of the personality and role of heroes. No wonder medics and volunteers are considered heroes in the context of the war against this pandemic. Several cases of doctors and nurses who died as a result of contracting Covid-19 spread when carrying out their jobs expressed widely in various media and reinforced the impression that they were heroes who were at great risk. This poem expresses this cultural commonsense.

This poem contains a meaning unit that reveals the writer's world-view about human's dependency on the God, since the God owns the final determinancy of this pandemic problem. This is a reflection of the author's beliefs as a Muslim. This expression is common in many Muslim societies, namely praying to Allah for Allah's help. In fact, in mid-May 2020 the Ministry of Religion of the Republic of Indonesia and the National Disaster Management Agency (BNPB) held a joint prayer nationwide intended to pray to God to end the Covid-19 outbreak. President Joko Widodo and vice president Ma'ruf Amin attended the event.

Muhammad Jusuf Kalla was a former vice president of the Republic of Indonesia. He was a state official who loves to write poetry. Several years ago, in 2017, he read a poem he wrote especially as a gift for his 50th wedding anniversary to his wife, Mufidah. It was a celebration of Jusuf Kalla and Mufidah's golden anniversary. The event, which was held at the Dharmawangsa Hotel, Jakarta, on 27 
August 2017 was used by Jusuf Kalla to read his poem entitled Half a Beautiful Century. ${ }^{30}$

\section{Coronavirus Disease 2019 (Covid-19) by Sri Purnomo}

In addition to a poem with the title Corona Virus written by M. Jusuf Kalla (former vice president), a poem entitled Coronavirus Disease 2019 written by Sri Purnomo (active regent) is also circulating. ${ }^{31}$ The following is a poem by Sri Purnomo.

\section{Coronavirus Disease 2019 (Covid-19)}

Hadir duka nestapa berdesir, berpuluh telah luluh, beratus telah pupus. Tawa riang berganti kecamuk pikir, sungguh kesabaran yang jadikan kita lulus.

Telah satu purnama mencabik beribu jiwa, segala doa melangit penuhi cakrawala.

Bila ini peringatan untuk segala hamba, hanya kepada-Nya kita minta segala daya.

Angka demi angka bergerak, mencabut kesadaran kita.

Kewaspadaan jadi teman sepanjang jalan, anak-anak bangsa merenda cita bersama.

Kedamaian harus terus diperjuangkan, duhai Tuhan pemilik segala kekuasaan.

Segala upaya tak henti kami kerahkan, bilakah corona pergi dari detak kehidupan, jadikan ini pembelajaran atas pentingnya kemanusiaan. Kepada anak-anakku penerus masa depan Sleman, mari bersatu padu kita bergandengan tangan.

Tatap masa depan sepenuh keyakinan, segala ujian harus kita lalui sebagai satu pengabdian.

Pegang teguh wasiat leluhur bangsa kita, agar kita hamemayu hayuning bawono, berjuang berpeluh demi kehidupan bersama. Jaga kelestarian alam, agar damai bahagia sentosa, amin.

The English translation of the Poem is as follows:

\section{Coronavirus Disease 2019 (Covid-19).}

\section{Sri Purnomo}

Here comes the grief, tens have collapsed, hundreds have passed away.

30 (Jaramaya, 2020)

31 Wahyu Suryana, "Puisi Corona Bupati Sri: Kedamaian Harus Terus Diperjuangkan," Republika Online, April 16, 2020, https://republika.co.id/berita/q8vaw2396/puisi-corona-bupati-srikedamaian-harus-terus-diperjuangkan. 
Happy laughter changes to tangled minds, and only patients to bring us safe. A full moon has passed that ripped thousands of lives, and all prayers flew the sky to fill the heaven.

If this is meant to warn us, to Him God we beg.

Number by number moves up, unplugging our consciousness.

Alertness becomes a company, to build a dream for a brighter future.

A peaceful life is to be struggled, oh Lord, the owner of all power.

All the efforts we try ceaselessly, to make the corona away from our lives, And we take this as lesson learnt on the meaning of humanity.

To those my Sleman youth, let's unite and walk together hand in hand. Look up to the future convincingly, that these all challenges have to be faced as a consecration/devotion/dedication.

Embrace our ancestors' will, so we could hamemayu hayuning bawono,

To struggle and sweat for our life together.

Let's keep the sustainability of nature, for our peaceful and happy future, amen.

Tabel 2.

Content Analysis of the Poem Corona Virus Desease 2019.

\begin{tabular}{|l|l|l|l|l|}
\hline Meaning units & $\begin{array}{l}\text { Condensed } \\
\text { Meaning } \\
\text { Units }\end{array}$ & $\begin{array}{l}\text { Interpreta } \\
\text { tions of } \\
\text { condensed } \\
\text { meaning }\end{array}$ & Sub-theme & Theme \\
\hline $\begin{array}{l}\text { Here comes the } \\
\text { grief, tens have } \\
\text { collapsed, hundreds } \\
\text { have passed away. }\end{array}$ & $\begin{array}{l}\text { Corona has } \\
\text { claimed many } \\
\text { victims, } \\
\text { turning joy } \\
\text { into anxiety. It } \\
\text { takes patience } \\
\text { to get through laughter } \\
\text { changes to tangled } \\
\text { minds, and only } \\
\text { patients to bring us } \\
\text { safe. }\end{array}$ & $\begin{array}{l}\text { Corona } \\
\text { takes away } \\
\text { life and } \\
\text { joy, so we } \\
\text { need } \\
\text { patience. }\end{array}$ & $\begin{array}{l}\text { The } \\
\text { importance } \\
\text { of patience. }\end{array}$ & Be patience \\
\hline $\begin{array}{l}\text { A full moon has } \\
\text { passed that ripped } \\
\text { thousands of lives, } \\
\text { and all prayers flew } \\
\text { the sky to fill the } \\
\text { heaven. If this is } \\
\text { meant to warn us, to }\end{array}$ & $\begin{array}{l}\text { If this is God's } \\
\text { warning then } \\
\text { to Allah we } \\
\text { ask for help. }\end{array}$ & $\begin{array}{l}\text { Corona as a } \\
\text { warning, so } \\
\text { pray to } \\
\text { God. }\end{array}$ & $\begin{array}{l}\text { God is the } \\
\text { ultimate } \\
\text { determinance }\end{array}$ & . \\
\hline
\end{tabular}




\begin{tabular}{|c|c|c|c|c|}
\hline Him God we beg. & & & & \\
\hline $\begin{array}{l}\text { Number by number } \\
\text { moves up, } \\
\text { unplugging our } \\
\text { consciousness. } \\
\text { Alertness becomes } \\
\text { a company, the } \\
\text { nation's children } \\
\text { weave a common } \\
\text { goal, to build a } \\
\text { dream for a brighter } \\
\text { future. } \\
\text { A peaceful life is to } \\
\text { be struggled, }\end{array}$ & $\begin{array}{l}\text { The number of } \\
\text { victims } \\
\text { continues to } \\
\text { increase, it is } \\
\text { necessary to } \\
\text { be alert and } \\
\text { keep } \\
\text { togetherness of } \\
\text { the nation's } \\
\text { children to } \\
\text { achieve a } \\
\text { sense of peace. }\end{array}$ & $\begin{array}{l}\text { The } \\
\text { togethernes } \\
\text { s of } \\
\text { Indonesian } \\
\text { citizens is } \\
\text { needed to } \\
\text { face } \\
\text { corona. }\end{array}$ & $\begin{array}{l}\text { Togetherness } \\
\text { is needed. }\end{array}$ & Togetherness \\
\hline $\begin{array}{l}\text { oh Lord, the owner } \\
\text { of all power. All the } \\
\text { efforts we try } \\
\text { ceaselessly, to make } \\
\text { the corona away } \\
\text { from our lives, } \\
\text { And we take this as } \\
\text { lesson learnt on the } \\
\text { meaning of } \\
\text { humanity. }\end{array}$ & $\begin{array}{l}\text { Tell God that } \\
\text { all efforts will } \\
\text { continue and } \\
\text { hope that this } \\
\text { epidemic will } \\
\text { become a } \\
\text { lesson for } \\
\text { humanity. }\end{array}$ & $\begin{array}{l}\text { Hope for } \\
\text { God's help } \\
\text { and make } \\
\text { the plague } \\
\text { a lesson. }\end{array}$ & $\begin{array}{l}\text { Linking all } \\
\text { hopes to } \\
\text { God. }\end{array}$ & Hope on God \\
\hline $\begin{array}{l}\text { To those my } \\
\text { Sleman youth, let's } \\
\text { unite and walk } \\
\text { together hand in } \\
\text { hand. }\end{array}$ & $\begin{array}{l}\text { Urge the } \\
\text { Sleman youths } \\
\text { to unite and } \\
\text { fight against } \\
\text { this epidemic. }\end{array}$ & $\begin{array}{l}\text { The leader } \\
\text { urges } \\
\text { people to } \\
\text { unite to } \\
\text { work } \\
\text { together. }\end{array}$ & $\begin{array}{l}\text { Unity and } \\
\text { cooperation }\end{array}$ & $\begin{array}{l}\text { Unity and } \\
\text { cooperation. }\end{array}$ \\
\hline $\begin{array}{l}\text { Look up to the } \\
\text { future convincingly, } \\
\text { that these all } \\
\text { tests/challenges } \\
\text { have to be faced as } \\
\text { a consecration. }\end{array}$ & $\begin{array}{l}\text { Look at the } \\
\text { future with } \\
\text { optimism and } \\
\text { face the } \\
\text { pandemic as a } \\
\text { consecration. }\end{array}$ & $\begin{array}{l}\text { Be } \\
\text { optimistic } \\
\text { about the } \\
\text { corona } \\
\text { outbreak. }\end{array}$ & $\begin{array}{l}\text { Plague as a } \\
\text { test. facing it } \\
\text { as devotion. }\end{array}$ & $\begin{array}{l}\text { Facing the } \\
\text { plague as a } \\
\text { dedication }\end{array}$ \\
\hline $\begin{array}{l}\text { Embrace our } \\
\text { ancestors' will, so } \\
\text { we could } \\
\text { hamemayu } \\
\text { hayuning bawono, } \\
\text { To struggle and }\end{array}$ & $\begin{array}{l}\text { Uphold the } \\
\text { message to } \\
\text { strive for life } \\
\text { together and } \\
\text { balance with } \\
\text { nature. }\end{array}$ & $\begin{array}{l}\text { Message to } \\
\text { do good for } \\
\text { the world } \\
\text { for life } \\
\text { together. }\end{array}$ & $\begin{array}{l}\text { Cooperation } \\
\text { for } \\
\text { togetherness }\end{array}$ & $\begin{array}{l}\text { Cooperation } \\
\text { for } \\
\text { togetherness }\end{array}$ \\
\hline
\end{tabular}




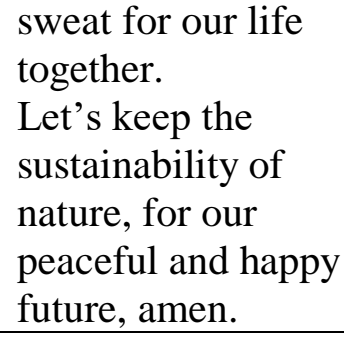

The meaning unit in Sri Purnomo's verse contains several main themes. The theme of suffering due to the Covid outbreak and patience in facing the pandemic are two of the important themes. This theme of patience is coupled with the theme of asking God for help in facing this pandemic. This theme of wishing in God appeared several times. This reflects the world-view (world-view) of the author and the wider public of Indonesian society regarding the faith in the relationship between human beings and God, and the magnitude of God's power. God has power over his creatures including the corona-19 virus. Therefore, asking God's help is the right way besides human efforts to end this plague. Still related to the theme of God's power, the corona pandemic is seen as a test from God, and efforts to face it are seen as dedication.

The theme of unity and cooperation in dealing with the Covid-19 pandemic is also an important theme in this poem. Purnomo urges his people, particularly the youth, to to unite and work together to fight the pandemic. This can be understood as a typical expression of a government leader (a bupati) in an area who has concern for the fate of its citizens and encourages citizens' participation in facing a threat.

In certain parts, Purnomo even uses the local language, Javanese, to convey his message in this poem. This reflects the ability of a local leader who understands how to communicate effectively with his people through culturally friendly expressions. In short, the theme of hope and dependence on God's help and the theme of the need for unity and cooperation among people are the two main themes that recur in this poem.

Sri Purnomo is the Regent of Sleman Yogyakarta. He wrote this poem and he read it when attending the Public Figure Reading Poetry Webinar held by the Association of Muslim Scholars throughout Indonesia (ICMI) in Yogyakarta (DIY). His poem entitled Coronavirus Disease 2019 (Covid-19) contains some important themes. We present the poem in Indonesian followed by an English translation.

\section{The Relations of the Poems}

In this section we briefly present the relationship between the two poems and reveal the thematic similarities they share. Briefly, the themes of the corona virus poem by M. Jusuf Kalla are the spread of the virus across spatial, social, sacred and profane boundaries; combining spirituality and real action; longing worship at mosque; the weakness of human; pray to the God; the importance of unity and mutual help as members of one nation; the value of sacrifice and devotion; etc. The themes of 
the Corona Virus Disease 2019 poem by Sri Purnomo briefly include corona takes away life and joy, so we need to be patience and vigilance; Corona is warning from God, so pray to God and be patience; weakness of human on the one hand and the power of God on the other hand, linking all hopes to God; God is the ultimate determinacy; the importance of unity and togetherness in facing the plague; the pandemic as a test, facing it as devotion and dedication.

First, the two poems contain objective descriptions according to the reality of the pandemic, namely a description of the symptoms of the pandemic and the destructive power of the covid-19 virus; all consequences of the virus in the form of victims of death and illness; also changes in human socio-cultural habits that are forced to be lived. Second, the two poems capture people's subjective emotions in the form of fear and panic, a sense of helplessness; hope and longing for God's help. Acknowledging human weakness and God's power is central in these poems. The dependence on Allah and Allah is the supreme protector. Third, the two poems contain the values and attitudes of leaders who care about the nation and its people. With a position as a leader, the authors encourage the need for optimism, unity, and cooperation between citizens in facing a pandemic.

These three groups of themes reflect culture in the form of how the authors interpret the COVID-19 pandemic, how cultural understanding and interpretation of these symptoms are, the influence of religious beliefs in interpreting and responding to the symptoms of the pandemic, as well as the orientation of cultural values reflected in the authors' expectations.

\section{Conclusion}

Public figures from governmental body are commonly perceived as people who are preoccupied with matters far from the world of art and literature. In Indonesia, not many public figures are capable of writing poem. Muhammad Jusuf Kalla and Sri Purnomo are the exceptions to this common phenomenon. Their verses not only describe an individual response to the Covid-19 pandemic but also reflect a cultural response to this pandemic since the poems reflect the commonsense views and feelings held by common people about covid-19 outbreak.

This study argues that the poems presented are part of the complexity of the cultural response to the Covid-19 pandemic. The cultural response to this pandemic certaintly takes various forms. Poetry, however, has a special place in this issue because in poetry ratio and taste can be mixed, while world views, value systems, cultural meanings, pragmatism, emotions, and beliefs are linked together in meaning units. In the two poems about the COVID-19 pandemic analized in this article, the author's knowledge, emotions, beliefs, and individual hopes record and reflect back on the emotions, hopes, values, beliefs prevailing in the wider society in which the author becomes part of.

In the two poems, the main themes that emerge as the results of the content analysis are themes regarding the reality of the dangers of the Covid-19 pandemic, 
encouragement of patience, praise for self-sacrificing, and sincere attitudes for paramedics and volunteers and appreciation for them. There is also a theme of suggestions for increasing optimism, unity, and cooperation in dealing with this pandemic. The two poems also interpret the pandemic as God's trial. The theme of hoping and praying to God is the very central theme of the two poems. All of these themes illustrate the cultural world-views and values prevailing in society.

This article has shown that poem is not born from empty space. It is born from a particular socio-cultural context. In other words, in anthropological view, poem reflects sociocultural life and at the same time, it responds to the developments in the socio-cultural life. In wider sense, poetry and socio-cultural reality contain dialectical relationship between reflections of reality and responses to reality. It is in this context that poetry as a cultural response to the Covid-19 pandemic has its strong meaning. As a final point, this study contributes to an understanding of the complexity of the community's response to the COVID-19 pandemic, particularly from the aspect of cultural production in the form of poetry works.

\section{E. Acknowledgments}

We would like to express gratitude to the Faculty of Cultural Science of Universitas Khairun for financial and administrative support to our study under PKUPT research scheme.

\section{BIBLIOGRAPHY}

Abdullah, Irwan. "Psychological Trauma: Theory, Research, Practice, and Policy COVID-19: Threat and Fear in Indonesia." American Psychological Association, 2020.

Abu-Lughod, Lila. "The Interpretation of Culture(s) after Television." In The Fate of "Culture": Geertz and Beyond. Berkeley: University of Califronia Press, 1999.

Antara, Adinda Pryanka, and Sapto Andika Candra. "Empat Sektor Ekonomi Yang Paling Tertekan Pandemi Covid-19," 2020.

Bourdieu, Pierre. Outline of a Theory of Practice. Outline of a Theory of Practice. Cambridge: Cambridge University 1977. https://doi.org/10.1017/cbo9780511812507.

Bruijn, M.E. de. "The Sahelian Crisis and the Poor: The Role of Islam in Social 
Security among Fulbe Pastoralists, Central Mali." Focaal: Tijdschrift Voor AntropologieFocaal 22/23, no. 47 (1994).

Cnnindonesia.com. "Bukan 2 Juta, Kadin Sebut Korban PHK Akibat Corona 15 Juta," 2020.

Corbin J., \& Strauss, A. Basic of Qualitative Research: Techniques and Procedures for Developing Grounded Theory (3rd Edition). 3rd ed. Thousand Oaks: SAGE Publications, Inc, 2008.

Costello, Leesa, Marie-Louise McDermott, and Ruth Wallace. "Netnography." International Journal of Qualitative Methods 16, no. 1 (December 2017): 160940691770064. https://doi.org/10.1177/1609406917700647.

Dijk, J. W. M. van. "Livestock Transfers and Social Security in Fulbe Society in the Hayre, Central Mali." In Coping with Insecurity: An Underall Perspective on Social Security in the Third World, 97-112, 1994.

Eindhoven, Myrna. "Penjajah Baru? Identitas, Representasi, Dan Pemerintahan Baru, Di Kepulauan Mentawai Pasca-Orde.” In Politik Lokal Di Indonesia, edited by H.S. Nordholt and G. van Klinken, 87-115. Jakarta: Yayasan Obor, 2007.

Foster, R. "Making National Cultures In The Global Ecumene." Annual Review of Anthropology 20, no. 1 (1991): https://doi.org/10.1146/annurev.anthro.20.1.235.

Geertz, Clifford. The Interpretation of Cultures. New York: Basic Books, 1973.

Gellner, Ernest. $N$ Ations and $N$ Ationalism. 1st ed. New York: Cornell University Press, 1983.

Hadyan, Rezha. "Survei ILO: Dua Dari Tiga Perusahaan Di Indonesia Berhenti Beroperasi." Ekonomi Bisnis, May 18, 2020. https://ekonomi.bisnis.com/read/20200518/12/1242174/survei-ilo-dua-daritiga-perusahaan-di-indonesia-berhenti-beroperasi.

Hill, Michael R. Sociology and Poetry: An Introduction. Sociological Origins 4: Spring, 2006. https://digitalcommons.unl.edu/sociologyfacpub/356.

Horkheimer, Max, and Theodor Adorno. Dialectic of the Enlightenment. London: Allen Lane, 1972.

Jaramaya, Rizky. "Puisi Romantis Jusuf Kalla Yang Buat Mufidah Tersipu." $\begin{array}{llll}\text { Republika } \quad \text { Online, } & \text { August }\end{array}$ https://republika.co.id/berita/ovdw5f330/puisi-romantis-jusuf-kalla-yang-buatmufidah-tersipu.

Kozinets, R. Netnography: Doing Ethnography Research Online. London: SAGE Publications, Inc, 2010. 
Kumalasari, Intan. "Viral, Ini 7 Potret Unik 'Lockdown' Di Berbagai Desa Di Indonesia." Merdeka, March 28, 2020. https://www.merdeka.com/sumut/7potret-unik-lockdown-di-berbagai-daerah-di-indonesia.html.

Li, Tania M. “Adat Di Sulawesi Tengah: Penerapan Kontemporer.” In Adat Dalam Politik Indonesia, edited by Jamie S. Davidson, David Henley, and Moniaga Sandra. Jakarta: KITLV, 2010.

Marchio Irfan Gorbiano, and Budi Sutrisno. "Jokowi Refuses to Impose Lockdown on Jakarta,” 2020.

Maribeth, Erb. "Kebangkitan Adat Di Flores Barat: Budaya, Agama, Dan Tanah.” In Adat Dalam Politik Indonesia, edited by David Henley Jamie S. Davidson and Sandra Moniaga. KITLV, 2010.

NG, Jefferson. "Can Indonesia's Fight against COVID-19 Overcome Troubled Central-Regional Coordination?" New Mandala, April 28, 2020. https://www.newmandala.org/can-indonesias-fight-against-covid-19overcome-troubled-central-regional-coordination/.

Nordholt, H. S. "Bali: Sebuah Benteng Terbuka." In Politik Lokal Di Indonesia, edited by H.S. Nordholt and G. van Klinken. Jakarta: Yayasan Obor, 2007.

Nugraheny, Dian Erika. "Mendagri Tak Setuju Pemprov Papua Tutup Wilayah Akibat Covid-19." Kompas, March 2020 https://nasional.kompas.com/read/2020/03/25/07591621/mendagri-tak-setujupemprov-papua-tutup-wilayah-akibat-covid-19?page=all.

Patton, Michael Quinn. Qualitative Research \& Evaluation Methods. 4th ed. California: SAGE Publications, Inc, 2015.

Power, Dominic, and Allen J.Scott. Cultural Industries and the Production of Culture. Edited by Dominic Power Allen J.Scott. 1st ed. New York: Routledge, 2004.

Prasetyo, Andhika. "Presiden: Ekonomi Indonesia Akan Sangat Berat." Media Indonesia, June 19, 2020. https://mediaindonesia.com/ekonomi/321836/presiden-ekonomi-indonesiaakan-sangat-berat.

Republika.co.id. "Ini Puisi JK Soal Pandemi Covid-19,” 2020.

Supriatin. "3 Kebijakan Anies Baswedan Dibatalkan Pemerintah Pusat." Merdeka, April 1, 2020. https://www.merdeka.com/jakarta/3-kebijakan-anies-baswedandibatalkan-pemerintah-pusat.html.

Suryana, Wahyu. "Puisi Corona Bupati Sri: Kedamaian Harus Terus Diperjuangkan." Republika Online, April $\quad 16, \quad 2020$ https://republika.co.id/berita/q8vaw2396/puisi-corona-bupati-sri-kedamaian- 
harus-terus-diperjuangkan.

Susilawati, Susilawati, Reinpal Falefi, and Agus Purwoko. "Impact of COVID-19's Pandemic on the Economy of Indonesia." Budapest International Research and Critics Institute (BIRCI-Journal): Humanities and Social Sciences, 2020. https://doi.org/10.33258/birci.v3i2.954. 


\section{Guidelines}

\section{Submission of Article}

urnal Adabiyah welcomes the articles submission with the main themes on Humanities and Islamic Studies with the emphasis on interdisciplinary and intertextuality approach. Adabiyah is thematicly published twice in a year. ie the theme of the humanities in June and the Islamic Study in December.

Themes related to Islamic Studies are textual studies, scriptural traditions, Islamic law, and theology; and those related to Humanities are language, literature, history, and culture. This scholarly journal Guarantees that the editor decision based on the peer review results will not exceed 30 days from the paper submission date.

Authors are invited to read our archives; to find the relevant topics for the journal, and to submit complete unpublished scientific researches, which are not under review in any other conferences or academic journal.

\section{PUBLICATION ETHIC}

Publication Ethic and Malpractice Statement

Jurnal Adabiyah is a peer-reviewed journal, published twice a year by the Faculty of Adab and Humaniora, Alauddin State Islamic University of Makassar Indonesia. It is available online as open access sources as well as in print. This statement clarifies ethical behaviour of all parties involved in the act of publishing an article in this journal, including the author, the editor-in-chief, the Editorial Board, the reviewers, and the publisher. This statement is based on COPE's Best Practice Guidelines for Journal Editors.

Ethical Guideline for Journal Publication

The publication of an article in Jurnal Adabiyah, is an essential building block in the development of a coherent and respected network of knowledge. It is a direct reflection of the quality of the work of the authors and the institutions that support them. Peer-reviewed articles support and embody the scientific methods. It is therefore important to agree upon standards of expected ethical behavior for all parties involved in the act of publishing: the author, the editor, the reviewer, the publisher, and the society. As the publisher of Jurnal Adabiyah, the Faculty of Adab and Humaniora takes its duties of guardianship over all stages of publishing seriously and it recognizes its ethical and other responsibilities. The Faculty of Adab and Humaniora committed to ensuring that advertising, reprint or other commercial revenue has no impact or influence on editorial decisions.

\section{Publication Decisions}

The editors of Jurnal Adabiyah is responsible for deciding which articles submitted to the journal should be published. The validation of the work in question and its importance to researchers and readers must always drive such decisions. The editors may be guided by the policies of the journal's editorial board and constrained by such legal requirements as shall then be in force regarding libel, copyright infringement, and plagiarism. The editors may confer with other editors or reviewers in making their decisions.

\section{Plagiarism Screening}

It is basically author's duty to only submit a manuscript that is free from plagiarism and academically malpractices. The editor, however, will check all submitted papers through Turnitin.

\section{Fair Play}

An editor at any time evaluates manuscripts for their intellectual content without regard to race, gender, sexual orientation, religious belief, ethnic origin, citizenship, or political philosophy of the authors. 


\section{Confidentiality}

The editors and any editorial staff must not disclose any information about a submitted manuscript to anyone other than the corresponding author, reviewers, potential reviewers, other editorial advisers, and the publisher, as appropriate.

\section{Disclosure and Conflicts of Interest}

Unpublished materials disclosed in a submitted manuscript must not be used in editors' own research without the express written consent of the author.

\section{DUTIES OF AUTHORS}

\section{Reporting Standards}

Authors of reports of original research should present an accurate account of the work performed as well as an objective discussion of its significance. Underlying data should be represented accurately in the paper. A paper should contain sufficient detail and references to permit others to replicate the work. Fraudulent or knowingly inaccurate statements constitute unethical behaviour and are unacceptable.

\section{Originality and Plagiarism}

The authors should ensure that they have written entirely original works, and if the authors have used the work and/or words of others that this has been appropriately cited or quoted.

\section{Multiple, Redundant, or Concurrent Publication}

An author should not in general publish manuscripts describing essentially the same research in more than one journal or primary publication. Submitting the same manuscript to more than one journal concurrently constitutes unethical publishing behaviour and is unacceptable.

\section{Acknowledgement of Sources}

Proper acknowledgment of the work of others must always be given. Authors should cite publications that have been influential in determining the nature of the reported work.

\section{Authorship of the Paper}

Authorship should be limited to those who have made a significant contribution to the conception, design, execution, or interpretation of the reported research. All those who have made significant contributions should be listed as co-authors. Where there are others who have participated in certain substantive aspects of the research project, they should be acknowledged or listed as contributors. The corresponding author should ensure that all appropriate co-authors and no inappropriate co-authors are included on the paper, and that all co-authors have seen and approved the final version of the paper and have agreed to its submission for publication.

\section{Disclosure and Conflicts of Interest}

All authors should disclose in their manuscript any financial or other substantive conflict of interest that might be construed to influence the results or interpretation of their manuscript. All sources of financial support for the project should be disclosed.

\section{Fundamental errors in Published Works}

When an author discovers a significant error or inaccuracy in his/her own published work, it is the author's obligation to promptly notify the journal editor or publisher and cooperate with the editor to retract or correct the paper.

\section{PLAGIARISM}

It is basically author's duty to only submit a manuscript that is free from plagiarism and academically malpractices. The editor, however, will check all submitted papers through Turnitin. 


\section{AUTHOR GUIDELINES}

\section{Guidelines for online submission:}

1. Author should first register as Author to the website of Jurnal Adabiyah. Click the menu "register" to register as an author.

2. Once after the author is registered, please login to the website of Jurnal Adabiyah and submit the article through online submission (with the stat us of active submissions).

3. The article should follow the standard template of Jurnal Adabiyah provided in the website.

4. The citation and bibliography should follow the Turabian citation style.

5. Author is restricted not to send his/her article to another journal before having confirmation from the editorial team (approximately 4 weeks right after the article submitted).

6. Author should follow editorial decisions and recommendations related to the article completion. All reviews and assessements will be informed through online submission.

Article submitted to Jurnal Adabiyah editorial board must follow these guidelines:

1. Article should be based on the scientific research in the field humanities and Islamic studies;

2. Article must be an original work and has not been previously published;

3. Article should be written in Arabic or English languages;

4. Article must be typed in one-half spaced on A4-paper size;

5. Article's length is about $6,000-10,000$ words;

6. All submission must include a 150-250 word abstract;

7. Abstract should be written in 3 languages; Arabic, English, and Bahasa;

8. Full name(s) of the author(s) must be stated, along with his/her/their institution and complete address;

9. All submission should be in OpenOffice, Microsoft Word, RTF, or WordPerfect document file format;

10. Bibliographical reference must be noted in footnote and bibliography according to Jurnal Adabiyah style. In addition, it is suggested for author(s) to use reference manager tools such

\section{as MENDELEY or 7 otero}

When a source is cited for the first time, full information is provided: full name(s) of author(s), title of the source in italic, place of publication, publishing company, date of publication, and the precise page that is cited. For the following citations of the same source, list the author's last name, two or three words of the title, and the specific page number(s). The word ibid., op.cit., and loc.cit. are may not be used any more.

\section{Example in footnotes:}

${ }^{1}$ Mircea Eliade (ed.), The Encyclopedia of Religion, vol. 8 (New York: Simon and Schuster, 1995), h. 18.

${ }^{2}$ Norman Daniel, Islam and the West (Oxford: One World Publications, 1991), h. 190.

${ }^{3}$ Syeikh Ja'far Subhāni, Mafăhim Al-Qur'ān (Beirut: Mu'assasah Al-Tarīkh Al-'Arabī, 2010)., Juz 5, h. 231. 
${ }^{4}$ Syeikh Ja'far Subhānī, Mafāhim Al-Qur'ān, h. 8-9.

\section{Example in bibliography:}

Subhānī, Syeikh Ja'far. Mafăhim Al-Qur'ān. Beirut: Mu'assasah Al-Tarīkh Al-’Arabī, 2010.

Eliade, Mircea (ed.). The Encyclopedia of Religion, vol. 8. New York: Simon and Schuster, 1995.

Daniel, Norman. Islam and the West. Oxford: One World Publications, 1991.

Shihab, Muhammad Quraish. Sunnah-Syiah Bergandengan Tangan: Mungkinkah? Kajian Atas Konsep Ajaran Dan Pemikiran. Cet. III. Jakarta: Lentera Hati, 2007.

\section{Detail informations of the footnotes:}

1. Holy book

Al-Qur'ân, Al-Baqarah/2: 185.

Perjanjian Baru, Mrk. 2: 18.

2. Qur'anic translation

${ }^{1}$ Departemen Agama RI, al-Qur'an dan Terjemahannya (Jakarta: Darus Sunnah, 2005), h. 55.

3. Book

${ }^{1}$ Muḥammad 'Ajjaj al-Khațib, Ușl al-Hadith: 'Ulumuh wa Mușțalaḥ uh (Beirut: Dâr al-Fikr, 1989), h. 57.

4. Translation Books

${ }^{1}$ Toshihiko Izutsu, Relasi Tuhan dan Manusia: Pendekatan Semantik terhadap al-Qur'an, terj. Agus Fahri Husein dkk (Yogyakarta: Tiara Wacana, 2003), h. 14.

5. Voluminous book

${ }^{1}$ Muḥammad al-Ṭâhir b. 'Ashur, al-Tahrīir wa al-Tanwīr, Vol. 25 (Tunisia: Dâr al-Suhûn, 2009), h. 76.

${ }^{1}$ Muḥammad b. Ismā‘īl al-Bukharī, al-Jami‘ al-Ṣaḥịh, Vol. 2 (Beirut: Dar al-Kutub al-‘Ilmı́yah, 1999), h. 77.

6. Article in book

${ }^{1}$ Sahiron Syamsuddin, "Metode Intratekstualitas Muhammad Shahrur dalam Penafsiran al-Qur'an" dalam Abdul Mustaqim dan Sahiron Syamsuddin (eds.), Studi al-Qur'an Kontemporer: Wacana Baru Berbagai Metodologi Tafsir (Yogyakarta: Tiara Wacana, 2002), h. 139.

7. Article in encyclopaedia

${ }^{1}$ M. Th. Houtsma, "Kufr" dalam A. J. Wensinck, at al. (ed.), First Encyclopaedia of Islam, Vol. 6 (Leiden: E.J. Brill, 1987), h. 244.

8. Article in journal

${ }^{1}$ Muhammad Adlin Sila, "The Festivity of Maulid Nabi in Cikoang, South Sulawesi: Between Remembering and Exaggerating the Spirit of Prophet", Studia Islamika 8, no. 3 (2001): h. 9.

9. Article in mass media

${ }^{1}$ Masdar F. Mas'udi, "Hubungan Agama dan Negara”, Kompas, 7 Agustus 2002. 
10. Article in Internet

${ }^{1}$ Muhammad Shahrūr, "Reading the Religious Teks: a New Approach" dalam http://www.shahrour.org/25 Februari 2010/diakses 5 Juni 2010.

11. Thesis or dissertation

${ }^{1}$ Syahruddin Usman, "KinerjaGuru Penddikan Agama Islam pada SMAN dan SMKN Kota Makassar”, Disertasi (Makassar: PPs UIN Alauddin, 2010), h. 200.

\section{COPYRIGHT NOTICE}

Authors who publish with this journal agree to the following terms:

1) Authors retain copyright and grant the journal right of first publication with the work simultaneously licensed under a Creative Commons Attribution License that allows others to share the work with an acknowledgement of the work's authorship and initial publication in this journal.

2) Authors are able to enter into separate, additional contractual arrangements for the non-exclusive distribution of the journal's published version of the work (e.g., post it to an institutional repository or publish it in a book), with an acknowledgement of its initial publication in this journal.

3)Authors are permitted and encouraged to post their work online (e.g., in institutional repositories or on their website) prior to and during the submission process, as it can lead to productive exchanges, as well as earlier and greater citation of published work (See The Effect of Open Access). 